\title{
Kızılçam ve Karaçam Tohum Bahçelerinde Gen Çeşitliliği
}

\author{
Nebi BİLíR \\ Isparta Uygulamalı Bilimler Üniversitesi, Orman Fakültesi, Isparta \\ Geliş Tarihi (Received): 28.03.2021, Kabul Tarihi (Accepted): 30.04.2021 \\ $\square$ Sorumlu Yazar (Corresponding author): nebibilir@isparta.edu.tr \\ (C) +902462146476 둉 +902462146599
}

\section{ÖZ}

Bu çalışma, Kızılçam (Pinus brutia Ten.) ve Karaçam (Pinus nigra Arnold.)'ın 2003 yılı öncesinde tesis edilen, günümüzde 20'si iptal edilen olmak üzere 113 klonal tohum bahçesi üzerinde gerçekleştirilmiştir. Orman Ağaçları ve Tohumları Islah Araştırma Enstitüsü Müdürlüğü'nden sağlanan veriler ışığında, çalışmaya konu tohum bahçelerinde, etkili klon sayıları hesaplanmış ve bu parametre yardımıyla, gen çeşitliliği tahmin edilerek, tesis edilen ve edilecek tohum bahçelerinin bakım, idare ve diğer uygulamalarına katkı sağlanması amaçlanmıştır. Çalışma sonucunda, bahçeler arası geniş farklılık bulunmakla birlikte, aktif Kızılçam tohum bahçelerinde ortalama klon sayısı 40,7, etkili klon sayısı 32,0 (etkili klon yüzdesi \%85,1) ve gen çeşitliği 0,982 tahmin edilmiştir. Bu tahminler Karaçam'da sırasıyla 32,3, $28,2(\% 89,6)$ ve 0,981 'dir. İptal edilen tohum bahçeleri ise aktif tohum bahçelerinden daha düşük ortalama klon ve etkili klon sayısı ile gen çeşitliği değerlerine sahiptir. Buna bağlı olarak, tohum bahçesinin tesisinde kullanılan ramet sayısına ilişkin varyasyon katsayısı ise iptal edilen tohum bahçelerinde, aktif tohum bahçelerine oranla daha yüksektir. Çalışma sonuçları, tohum bahçelerinin tesis, ıslah ve bakım çalışmaları bağlamında tartışılarak, tohum bahçelerinin idaresine yönelik önerilerde bulunulmuştur.

Anahtar Kelimeler: Genetik, Islah, klon, ramet, varyasyon

\section{Gene Diversity in Seed Orchards of Brutian Pine and Black Pine}

\begin{abstract}
This study was carried out on 113 seed orchards which of removed 20 orchards established before 2003 of Brutian pine (Pinus brutia Ten.) and Black Pine (Pinus nigra Arnold.) by collected data from The Research Directorate of Forest Tree Seeds and Tree Breeding of Turkey. Effective number of clones and gene diversity were estimated in the orchards to contribute tending and other management practices of present seed orchards and establishment of the future orchards. While there were large differences among orchards and within species, averages were 40.7 for clone numbers, 32.0 ( $85.1 \%$ of clone number) for effective number of clone and 0.982 for gene diversity in active seed orchards of Brutian pine. They were 32.3, 28.2 (89.6\%) and 0.981 in in active seed orchards of Black pine, respectively. Removed seed orchards had lower averages of clone number, effective number of clone and gene diversity than active seed orchards in the both species opposite to coefficient of variation of ramet numbers used in establishment. Results of the study were discussed for establishment, breeding and tending practices of seed orchards to contribute management of the seed orchards.
\end{abstract}

Keywords: Genetic, breeding, clone, ramet, variation 


\section{Giriş}

Nüfus artışı, insanoğlunun orman ve orman ürünlerine olan ihtiyacını çeşitlendirerek artırdığı gibi, bu artışlar orman varlığını da olumsuz etkilemektedir. Birleşmiş Milletler Gıda ve Tarım Teşkilatı verilerine göre, 1990 yılında 4 milyar 128 milyon hektar olan orman varlığı, 2015 yılında 3 milyar 999 milyon hektara düşmüştür ve 1990-2000 yılları arasında her yıl yaklaşık 7 milyon hektar orman alanı elden çıkarılarak diğer kullanımlara dönüştürülmüştür. Bu dönüşüm 2010-2015 yılları arasında ise, dünya genelinde yıllık ortalama 3 milyon hektardır (FAO, 2015). 2019 yılı Türkiye ormancılık istatistiklerine göre, 9,66 milyon hektarı verimsiz olmak üzere Türkiye'de 22,74 milyon hektar orman alanı bulunmaktadır (URL-1, 2020). Bu orman varlığı içerisinde, çalışmaya konu Kızılçam (Pinus brutia Ten.) 2,2 milyon hektarı bozuk olmak üzere 5,7 milyon hektarda; Karaçam (Pinus nigra Arnold.) ise 1,5 milyon hektarı bozuk olmak üzere 4,4 milyon hektarda doğal yayılış göstermektedir. Dolayısıyla çalışmaya konu türler, Türkiye toplam ormanlarında \%44 (10,1 milyon hektar), bozuk orman alanlarında ise \%38'lik (3,7 milyon hektar) paya sahipitir. Türlerin bu geniş yayılış alanına bağlı olarak, ağaçlandırma çalışmalarında da yaygın olarak kullanılmaktadır. Ayan ve ark. (2017) Karaçam'ın Türkiye ağaçlandırma uygulamalarında en yaygın kullanılan tür olduğunu belirtmektedir. Generatif veya vejetatif materyalle tesis edilen tohum bahçeleri, ıslah edilmiş ve kaliteli tohum üretimi ile ağaçlandırma, restorasyon vb. orman tesisi ya da verimsiz ormanların ıslahı uygulamalarında en yaygın kullanılan tohum kaynaklarıdır. Bu tohum kaynaklarının tesisinde kullanılan klon, rametlerle temsil edilmektedir ve bu rametler yetiştirme, dikim/tutma başarısı nedeniyle, sayısal bakımdan klon temsilini sağlamaktan uzaklaşabilmektedir. Buna bağlı olarak tohum bahçesinin biyolojik ve ekonomik başarısında rol oynayan klon sayılarının gen havuzuna katılım ve buna bağlı olarak gen çeşitliliğini olumsuz etkileyebilmekte ve bu klon sayısı etkili klon sayısı olarak adlandırılmaktadır (Kang ve ark., 2001; Bilir ve Ayan, 2005). Türkiye'de, 12 orman ağacı türünde 1443,3 hektar alanda 185 adet tohum bahçesi tesis edilmiştir. Bu tohum bahçelerinden, 663,2 hektarda tesis edilen 78 bahçe Kızılçam'a, 473,1 hektarda tesis edilen 55 bahçe ise Karaçam türüne aittir (URL2,2021 ). Ancak bu tohum bahçelerinin tesisinde kullanılan klon sayısı, bahçe, tür ve ülkelere göre geniş farklılıklar göstermektedir (Kang ve ark., 2001; Zobel ve Talbert, 2003; Bilir ve ark., 2004; Lindgren ve Prescher, 2005; Bilir ve Ulusan, 2007; URL-2, 2021). Fazla sayıda klon kullanımı tesis maliyetini artırdığı ve uygulamaları zorlaştırdığı gibi, az sayıda klon kullanımı da mevcut genetik çeşitliliğin gelecek kuşaklara aktarımını olumsuz etkileyebilmektedir (Bilir ve ark., 2004).
Bu bağlamda, çalışmada, 2003 yılı öncesinde tesis edilen ve mevcut ağaçlandırma uygulamalarında tohum kaynağı olarak önemli rol oynayan Kızılçam ve Karaçam tohum bahçeleri, klon ve ramet sayısı bakımından irdelenerek, gen havuzuna katkıyı gösteren etkili klon sayısı ve gen çeşitliliği ışığında mevcut tohum bahçelerinin idaresine ve ileride kurulacak bahçelerin tesisine yönelik önerilerde bulunulması amaçlanmıştır.

\section{MATERYAL VE YÖNTEM}

Çalışmada materyal olarak, 2003 yılı öncesinde tesis edilen ve mevcut ağaçlandırma uygulamalarında tohum kaynağı olarak önemli rol oynayan, 63'ü Kızılçam ve 50'si Karaçam olmak üzere 113 klonal tohum bahçesinin tesisinde kullanılan ve Orman Ağaçları ve Tohumları Islah Araştırma Enstitüsü Müdürlüğü'nden sağlanan klon ve ramet sayıları kullanılmıştır. Bu bahçelerden 9'u Kızılçam ve 11'i Karaçam'da olmak üzere 20'si ilgili Müdürlük tarafından iptal edilmiş olup, çaIışma kapsamında bu bahçeler klon sayısı, etkili klon sayısı ve gen çeşitliliği bağlamında, aktif ve iptal edilen tohum bahçeleri olarak ayrı ayrı değerlendirilmiştir.

Tohum bahçelerinde etkili klon sayısı $\left(\mathrm{N}_{c}\right)$ aşağıdaki eşitlik yardımıyla tahmin edilmiştir (Kang ve ark., 2001).

$$
N_{c}=\frac{n^{2} \text { total }}{\sum_{i=1}^{N} n_{i}^{2}}=\frac{1}{\sum_{i=1}^{N}\left(\frac{n_{i}}{n_{\text {total }}}\right)^{2}}=\frac{1}{\sum_{i=1}^{N} r_{i}^{2}}
$$

Eşitlikte, $n_{\text {total }}$ toplam ramet sayısını; $n_{i}$ i. klonun ramet sayısını, $\mathrm{N}$ toplam klon sayısını ve $r_{i}$ ise i. klonun bahçedeki oranını göstermektedir.

Etkili klon sayısı, ramet sayısına ilişkin varyasyon katsayısına ( $\mathrm{C} v$ ) bağlı olarak aşağıdaki eşitlik yardımıyla da tahmin edilebilmektedir (Kang ve Lindgren, 1998; Kang ve ark., 2001):

$$
N_{c}=\frac{N}{C V^{2}+1}
$$

Tohum bahçelerinde gen çeşitliliği (GD) ise $G D=1$ $0.5 / \mathrm{N}_{c}$ eşitliği yardımıyla tahmin edilmiştir (Kang ve Lindgren, 1998). 


\section{BULGULAR VE TARTIŞMA}

\section{Etkili KIon Sayısı ve Yüzdesi, Gen Çeşitliliği}

Çalışmaya konu aktif tohum bahçelerinde, tür içi bahçeler arası geniş farklılık bulunmakla birlikte, Kızılçam tohum bahçelerinde, ortalama klon sayısı 40,7, etkili klon sayısı 32,0 (klon sayısının \%85'i), ramet sayısına ilişkin varyasyon katsayısı \%39,5 ve gen çeşitliği 0,982 tahmin edilmiştir (Tablo 1, Şekil 1).

Tablo 1. Aktif tohum bahçelerinde türlere göre ortalama klon sayısı $(N)$, etkili klon sayısı $\left(\mathrm{N}_{c}\right)$, etkili klon yüzdesi $\left(N_{r}\right)$, varyasyon katsayısı $(C v)$ ve gen çeşitliği $(G D)$ değerleri

\begin{tabular}{cccccc}
\hline Tür & $\mathbf{N}$ & $\mathbf{N}_{c}$ & $\mathbf{N}_{r}^{* *}$ & $\mathbf{C}_{\mathbf{V}}$ & $\mathbf{G D}$ \\
\hline \multirow{2}{*}{ Kızılçam } & 40,7 & 32,0 & 0,85 & 39,5 & 0,982 \\
& $(18-146)^{*}$ & $(15,9-85,1)$ & $(0,57-0,99)$ & $(2,6-86,3)$ & $(0,968-0,994)$ \\
\multirow{2}{*}{ Karaçam } & 32,3 & 28,2 & 0,90 & 31,5 & 0,981 \\
& $(10-120)$ & $(9,3-77,5)$ & $(0,65-0,99)$ & $(4,6-7,4)$ & $(0,976-0,994)$ \\
\hline
\end{tabular}

Kızılçam'ın aktif tohum bahçelerinde klon sayısı 18-146, etkili klon sayısı 15,8-85,1, gen çeşitliliği ise 0,968-0,994 arasında değişim göstermiştir (Tablo 1). Örneğin bu bahçelerden, $18 \mathrm{klon}$ ve 384 ramet ile tesis edilen 10 nolu bahçenin 15,9 klonu (\%88,1); 146 klonla tesis edilen 155 nolu bahçenin ise $85,1^{\prime} i$ gen havuzuna önemli katkı sağlamaktadır. Diğer bir ifadeyle 155 nolu bahçede 146 klonun yaklaşık 61'i ramet sayısı bağlamında gen havuzunda pasif durumdadır. Bilir ve Ayan (2005) tarafından Doğu ladini (Picea orientalis (L.) tohum bahçelerinde gerçekleştirilen çalışmada, klon sayısının 30- 50; etkili klon sayısı 19,8 (etkili klon yüzdesi: \%66)- 39,6 (etkili klon yüzdesi: \%79) ve ramet sayısına ilişkin varyasyon katsayılarının \%18- \%72 arasında değiştiği belirlenmiştir. Türkiye'de tesis edilen 22 Sarıçam (Pinus sylvestris L.) tohum bahçesinde ise ortalama klon sayısı 41,0, etkili klon sayısı 37,3, etkili klon yüzdesi \%91,0 ve varyasyon katsayısı ise $\% 31,0$ bulunurken bu değerlerin sırasıyla 10-152, 9,9-145,3, \%76,0-\%99,0, \%85-\%55,6 arasında değiştiği bulunmuştur (Bilir ve Ulusan, 2007). Türkiye ormancılığının önemli türlerinden biri olan Toros sediri'nin (Cedrus libani A. Rich) 9 tohum bahçesi üzerinde gerçekleştirilen çalışmada, etkili klon sayısının 24,6-31,4, etkili klon yüzdesinin $\% 82,0-\% 99,0$ arasında değiştiği ortaya çıkmıştır (Ulusan ve Bilir, 2008).

Çalışmaya konu diğer tür olan Karaçam aktif tohum bahçelerinde, tür içi bahçeler arası geniş farklıılıla birlikte, ortalama klon sayısı, etkili klon sayısı, varyasyon katsayısı ve gen çeşitliği değerleri sırasıyla 32,3, 28,2 (\%90,0), \%31,5 ve 0,981 hesaplanmıştır (Tablo 1, Şekil 1). Karaçam'ın aktif tohum bahçelerinden 30 klon ile tesis edilen iki bahçesinden, 75 nolu bahçe için etkili klon sayısı 25 (\%83,5), 50 nolu bahçe için ise $29.8(\% 99,4)$ bulunmuş ve bu bahçelerin klonlara göre ramet dağılımı Şekil 2'de verilmiştir.
Gen çeşitliliği, biyotik ve abiyotik zararlılara karşı dayanıklı orman tesisinde kullanılabilecek önemli genetik parametrelerdendir. Bu parametrenin öneminin, küresel ısınma bağlamında kuraklığa dayanıklı ağaçlandırma, rehabilitasyon ve diğer ormancılık uygulamaları için daha da artacağı aşikardır. Etkili klon sayısı $\left(\mathrm{N}_{c}\right)$ ve gen çeşitliliği (GD), $G D=1-0,5 / N_{c}$ eşitliği (Kang ve Lindgren, 1998) ile doğrudan etkileşim içerisindedir. Bu etkileşim klonlara ait ramet sayısına ilişkin varyasyon katsayısı $\left(\mathrm{C} v\right.$ ) ve klon sayısı $\left(\mathrm{N}\right.$ ) ile $\mathrm{GD}=0,5-\mathrm{Cv}^{2} / \mathrm{N}$ (Kang ve Lindgren, 1998; Kang ve ark., 2001) şeklinde de ilişkilendirebilir ve dolayısıyla bu ilişkiler tohum bahçesinin tesisinde kullanılan klon sayısı ve klonların temsilinde kullanılan ramet sayısının aynı veya benzer sayıda olmasının önemini vurgulamaktadır. Örneğin, Kızılçam'ın 114 ve 73 klonla tesis edilen $164 \quad\left(\mathrm{C}_{\mathrm{v}=\% 86,1)}\right.$ ve 166 $\left(\mathrm{C}_{V}=\% 37,2\right)$ nolu iki tohum bahçesinde gen çeşitliliği 0.992 olarak tahmin edilmiştir. Bu sonuç gen çeşitliliğinde, klon sayısından ziyade ramet sayısı varyasyonunun önemini vurgulamaktadır. Ancak gen çeşitliliğinde polen sayısı, klon/rametlerin üretkenliği, toprak ve iklim özellikleri gibi bir çok faktörün rol oynayabileceği bilinmektedir.

Çalışmaya konu aktif Karaçam tohum bahçelerinde klon sayısı 10-120 arasında, Kızılçam'da ise 18-146 arasında değişim göstermektedir (Tablo 1). Bu geniş farklılık sadece çalışmaya konu türlerde değil, diğer tür ve ülkelerde de mevcuttur (Kang ve ark., 2001; Zobel ve Talbert, 2003; Lindgren ve Prescher, 2005). Ancak, Türkiye'deki dört doğal karaçam tohum meşceresi, tohum bahçesi ve ağaçlandırma sahalarında gerçekleştirilen moleküler genetik çalışmasında; elde edilen bulgular ışığında, tohum bahçesi tesisinde kullanılan plus ağaç sayısının (25-30) genetik çeşitliliği korumada yeterli olduğu belirlenmiştir (Velioğlu ve ark., 2003). Benzer sonuçlara üreme verimi yardımıyla tahmin edilen parametrelere göre, Kızılçam tohum bahçeleri için de ulaşılmıştır (Bilir ve ark., 2004). 

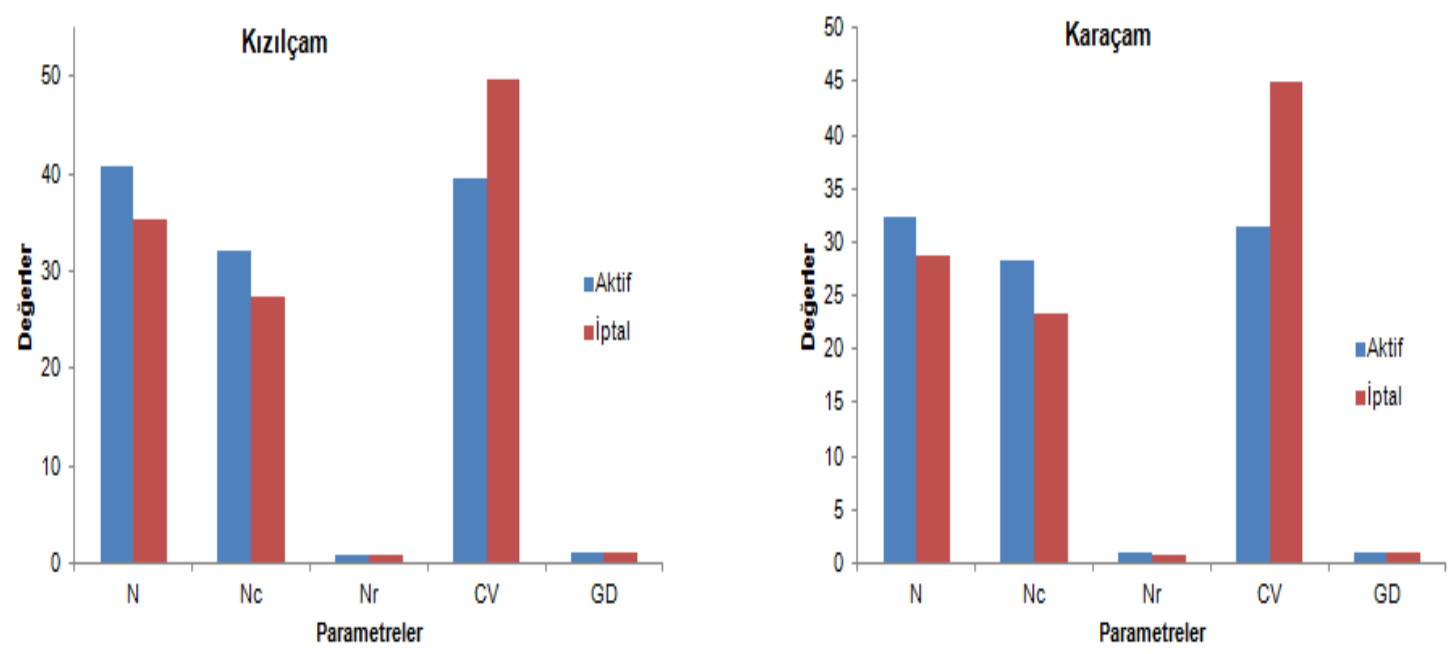

Şekil 1. Türlerin aktif ve iptal tohum bahçelerinde ortalama klon sayısı $(\mathrm{N})$, etkili klon sayısı $\left(\mathrm{N}_{c}\right)$, etkili klon oranı $\left(N_{r}\right)$, varyasyon katsayısı $(C v)$ ve gen çeşitliği (GD) değerleri
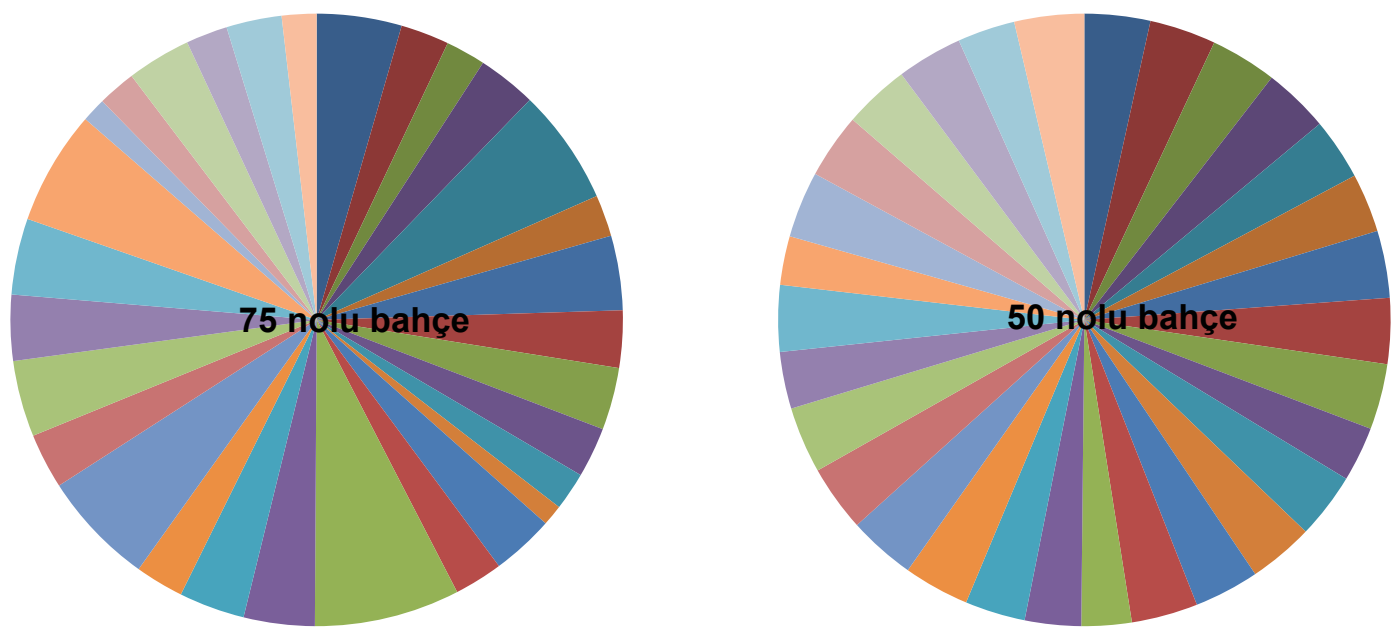

Şekil 2. 30 klon ile tesis edilen 75 ve 50 nolu Karaçam tohum bahçelerinde ramet sayısı dağılımı

Kızılçam'ın iptal edilen tohum bahçelerinde, ortalama klon sayısı 35,2, etkili klon sayısı 27,5 (klon sayısının $\% 80$ 'i), varyasyon katsayısı \%49,6 ve gen çeşitliği 0,974 tahmin edilmiştir. Bu tahminler Karaçam'ın iptal edilen tohum bahçelerinde ise, sırasıyla 28,8, 23,3 (\%83), $\% 45,0$ ve 0,977 tahmin edilmiştir (Tablo 2, Şekil 1). Dolayısıyla aktif Kızılçam ve Karaçam tohum bahçelerinde, etkili klon sayısı, yüzdesi ve gen çeşitliliğini olumsuz yönde etkileyen varyasyon katsayısı dışında diğer değerler daha yüksek bulunmuştur (Tablo 1 ve 2, Şekil 1) ve bu sonuçlar ışığında iptal edilen tohum bahçelerinin bilimsellikle (etkili klon sayısı ve gen çeşitliliği) uyum gösterdiği ve yerinde bir uygulama olduğu söylenebilir. 
Tablo 2. İptal edilen tohum bahçelerinde türlere göre ortalama klon sayısı $(N)$, etkili klon sayısı $\left(N_{c}\right)$, etkili klon yüzdesi $\left(\mathrm{N}_{r}\right)$, varyasyon katsayısı $\left(\mathrm{C}_{\mathrm{v}}\right)$ ve gen çeşitliği $(\mathrm{GD})$ değerleri

\begin{tabular}{cccccc}
\hline Tür & $\mathbf{N}$ & $\mathbf{N}_{c}$ & $\mathbf{N}_{r}^{* *}$ & $\mathbf{C}_{\mathrm{V}}$ & $\mathbf{G D}$ \\
\hline \multirow{2}{*}{ Kızılçam } & 35,3 & 27,5 & 0,80 & 49,6 & 0,974 \\
& $(10-77)^{*}$ & $(8,1-69,2)$ & $(0,54-0,97)$ & $(18,5-92,7)$ & $(0,938-0,993)$ \\
\multirow{2}{*}{ Karaçam } & 28,8 & 23,3 & 0,83 & 45,0 & 0,977 \\
& $(14-49)$ & $(12,7-33)$ & $(0,60-0,95)$ & $(22,5-88,2)$ & $(0,961-0,985)$ \\
\hline
\end{tabular}

Tohum bahçelerinin tesis aşaması veya sonrasında, biotik veya abiotik zararlılar nedeniyle klon veya ramet sayılarında değişim meydana gelebilmekte ve buna bağlı olarak veya orman yangını, düşük etkili klon sayısı ve gen çeşitliliği vb bilimsel nedenlerle tohum bahçesinin iptali söz konusu olabilmektedir. Aktif ve iptal edilen tohum bahçelerine ilişkin ortalama değerler ile etkili klon sayısı ve gen çeşitliliği değerlerinin irdelenmesi sonucu (Tablo 1 ve 2, Şekil 1); Orman Ağaçları ve Tohumları Islah Araştırma Enstitüsü Müdürlüğü tarafından tohum bahçeleri iptalinin, bilimsellikle uyum gösterdiği anlaşılmaktadır. Bununla birlikte, iptal edilen tohum bahçeleri yerine, tohum arz-talep dengesine bağlı olarak, Orman Ağaçları ve Tohumları Islah Araştırma Enstitüsü Müdürlüğü tarafından yeni bahçeler tesis edilmekte olup güncel istatitiksel verilere göre çalışmaya konu Kızılçam'ın 663,2 hektar alanda 78 , Karaçam'ın ise 473,1 hektar alanda 55 tohum bahçesi mevcuttur ve örneğin ilgili Müdürlük tarafından, 2019-2020 yıllarında Kızılçam'ın 24,3 hektarda beş, Karaçam'ın ise 7,6 hektarda bir tohum bahçesi tesis edilmiştir (URL-2, 2021). Tohum bahçeleri, vejetatif veya generatif materyal seçimi, hasadı, fidan yetiştirilmesi, tesis ve sonrasında bakımı olmak üzere birçok ekonomik ve biyolojik aşamaları içermektedir. Ancak, tohum bahçelerinin tesisinde optimal klon sayısının kullanımı ve bu klonların eşit ya da benzer sayıda ramet ile temsilinin tohum bahçesi maliyetini düşüreceği gibi biyolojik başarısını da artıracağı söylenebilir.

\section{SONUÇLAR}

Çalışmaya konu her iki türün aktif tohum bahçelerinde, türler arası ve tür içi bahçeler arası geniş farklılıklar bulunmakla birlikte Kızılçam'da ortalama klon sayısı 40,7, etkili klon sayısı 32,0 (\%85), ramet sayısına ilişkin varyasyon katsayısı $\% 39,5$ ve gen çeşitliği 0,982 tahmin edilirken, bu değerler Karaçam'da sırasıyla 32,3, 28,2 (\%90,0), \%31,5 ve 0,981 tahmin edilmiştir. Ancak, tür içi bahçeler arası klon sayısı varyasyonu ve bahçe içi ramet sayısı varyasyonu, ihtiyaç duyulması halinde genetiksel veya geleneksel bakım uygulamaları ile gen çeşitliliğini artırmaya yönelik olarak dengelenebilir.

Her iki türün aktif tohum bahçelerinde, etkili klon sayısı ve gen çeşitliliğini olumsuz yönde etkileyen varyasyon katsayısı dışında diğer değerlerin daha yüksek olduğu ortaya çıkmış ve bu sonuçlar, iptal edilen tohum bahçelerinin düşük etkili klon sayısı ve gen çeşitliliği bağlamında bilimsellikle uyum gösterdiğini ve yerinde bir uygulama olduğu göstermiştir.

Gen çeşitliliği üzerine bir çok çevresel ve biyolojik faktörün etkili olduğu bilinmekle birlikte, çalışma sonucunda, gen çeşitliliğinde, klon sayısından ziyade ramet sayısı varyasyonunun önemli olduğu ortaya çıkmıştır.

Gerek çalışmaya konu tohum bahçelerinde ve gerekse diğer tohum bahçelerinde, bahçe tesisinde kullanılan klon sayıları geniş farklılıklar göstermekle birlikte tohum bahçelerinin tesisinde optimal klon sayısının kullanımı ve bu klonların eşit ya da benzer sayıda ramet ile temsilinin tohum bahçesi maliyetini düşüreceği ve bahçenin biyolojik başarısını artırarak tesis amacına daha uygun olacağı söylenebilir.

\section{TEŞEKKÜR}

Çalışma verilerini sağlayan Orman Ağaçları ve Tohumları Islah Araştırma Enstitüsü Müdürlüğü'nün önceki ve mevcut yönetim ve çalışanlarına teşekkür ederim.

\section{KAYNAKLAR}

Ayan, S., Yer, E.N., Gülseven, O. (2017). Türkiye'deki Toros Sediri (Cedrus libani A. Rich.) Ağaçlandırma Sahalarının İklim Tipi Açısından Değerlendirilmesi. Artvin Çoruh Üniversitesi Orman Fakültesi Dergisi, 18(2):152-161.

Bilir, N., Kang, K. S., Zang, D., Lindgren, D. (2004). Fertility Variation and Status Number Between a Base Population and a Seed Orchard of Pinus brutia. Silvae Genetica, 53(1-6):161-163.

Bilir, N., Ulusan, M.D. (2007). Seed Orchards and Seed Collection Stands of Scots Pine in Turkey. International Seed Orchard Conference, 26-28 September, 25-36, Umea, Sweden.

Bilir, N., Ayan, S. 2005. Doğu Ladini Tohum Bahçelerinde Etkili Klon Sayısı. Ladin Sempozyumu, 20-22 Ekim, Cilt I, 457-464, Trabzon.

FAO (2015). Global Forest Resources Assessment 2015. Food and Agriculture Organization of the United Nations, Rome, Italy. 
Kang, K.S., Harju, A.M., Lindgren, D., Nikkanen, T., Almqvist, C., Suh, G.U. (2001). Variation in Effective Number of Clones in Seed Orchards. New Forests, 21(1):17-33.

Kang, K.S., Lindgren, D. (1998). Fertility Variation and Its Effect on the Relatedness of Seeds in Pinus densiflora, Pinus thunbergii and Pinus koraiensis Clonal Seed Orchards. Silvae Genetica, 47(4): 196-201.

Lindgren, D., Prescher, F. (2005). Optimal Clone Number for Seed Orchards with Tested Clones. Silvae Genetica, 54(2):80-92.

Ulusan, M.D., Bilir, N. (2008). Effective Number of Clones in Seed Orchards of Cedrus libani A. Rich. Pakistan Journal of Biological Sciences, 11(17):1592162.
URL-1 (2020). https://www.ogm.gov.tr (Erişim Tarihi: $01.12 .2020)$

URL-2 (2021). https://www. ortohum.gov.tr (Erişim Tarihi: 15.01.2021)

Velioğlu, E., Çengel, B., İçgen, Y., Kandemir, G., Alan, M., Kaya, Z. (2003). Moleküler Belirteçler Yardımıyla Karaçam (Pinus nigra Arnold subspecies pallasiana (Lamb.) Holmboe.) Tohum Meşcerelerinde, Tohum Bahçelerinde ve Ağaçlandırmalarında Bulunan Genetik Çeşitliliğin Karşılaştırılması. Orman Ağaçları ve Tohumları Islah Araştırma Enstitüsü Müdürlüğü, Teknik Bülten No:11.

Zobel, B.J., Talbert, J. (2003). Applied Forest Tree Improvement. Blackburn Press, New Jersey, USA. 